\title{
DEFINITION AND RESEARCH METHODS OF UZBEK MODERN LITERATURE
}

\author{
Umriniso Rahmatovna Toraeva
}

Bukhara State University Uzbekistan

\section{ABSTRACT}

The present paper discusses the Tatar press and Turkestan Jadidism in the researches of Begali Kasimov.

The paper gives detailed analysis and valuable information on the related work and it

will look through researches conducted by Uzbek and international scholars. Furthermore, the

newspapers, magazines and presses are taken as a main point of discussion.

KEYWORDS: - Jadidism, Jadid literature, hermeneutic, sociological, biographical, comparative-historical, comparative-typological methods.

\section{INTRODUCTION}

The study of the scientific methods of eminent researcher scholars, the methods of researching certain literary sources, is considered important in two respects. The first aspect: it allows experienced scientists to study the criteria of approach to the object of research, research methods. The second aspect: it is very important for young researchers entering the field of science to have a deep penetration into the scientific laboratory of master scientists, to learn from it. In this regard, it is important to study the research methods of Professor Begali Kasimov in his research on the national revival and modern literature.

In Begali Kasimov's research we can observe the effective use of several scientific research methods at the same time. This feature is clearly reflected in the research of the scientist on the national revival and the activities of modern Uzbek artists. It is important to study the scientific methods used by the scientist, their role in the study of the work of modern artists, and at the same time lead to interesting scientific conclusions.

In his research, the scientist effectively used the possibility of hermeneutic, sociological, biographical, comparative-historical, comparative-typological methods.

One of the most widely used methods in B. Kasimov's research is the hermeneutic method. In these studies, hermeneutics has been variously described as part-by-part and, conversely, part-by-part, consistent interpretation of written sources, teaching about the art of deep understanding, and methods of understanding the features of thought, language, 
CURRENT RESEARCH JOURNAL OF PHILOLOGICAL SCIENCES 2(10): 104-

107, October 2021

DOI: https://doi.org/10.37547/philological-crjps-02-10-20

ISSN 2767-3758

(C)2021 Master Journals

Crossref do

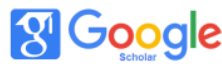

Accepted $26^{\text {th }}$ October, 2021 \& Published $31^{\text {th }}$ October, 2021

and speech. In recent years, as in world literature, in Uzbek literature, scientific works on this method have been created.

Sociological method. "It is known that this method is based on the view of fiction as a social phenomenon, and in the study of literature through this method, it is important to take into account social events, cultural environment, literary and historical conditions." Every artist lives in a certain historical period, in a certain social environment, and this fact inevitably affects his creativity. That is why Begali Kasimov effectively used the sociological method in his research.

Professor Begali Kasimov says about Mirmukhsin in his dissertation "Mirmukhsin (Fikri) and his literary environment": "He grew up to be intelligent. Initially, he graduated from a new school. In 1913, his first poem "Tavsifi Khislat Eshan" was published in the "Turkistan viloyat Gazeti". The poem is dedicated to the publication of the book "Argumoni Khislat" by Tashkent poet Hibbatullo Khislat.

Mirmukhsin clearly states in his works and articles that men and women should have equal rights in society, but that women have no place in this society and are subjected to humiliation and suffering. But that doesn't last long. Articles criticizing the Jadids 'nonsense about enlightenment were not published in the press. There was opposition to him in life and in the press."

The sociological method is especially evident in the scholar's research on the activities of modern enlighteners in his pamphlet Izlay-izlay findim.

The pamphlet "Izlay-izlay tapganim..." was created in 1983, in the study of Uzbek literature with a long history of development, 1905-1917 is considered as a period of great revolutionary uprisings, the people's struggle for freedom and liberty. In the poetry of these years, the human factor took the lead. It was a period of uncompromising struggle against all the rules and customs of the existing society. In a very short time, our poetry has become a revolutionary poetry in a fighting, belligerent spirit. Begali Kasimov in his book "Izlay-izlay tapganim" called the poetry of 1905-1917 "samples of revolutionary literature." However, the emergence of Uzbek revolutionary poetry in recent years, the stages of its formation, in general, the gradual development of the literature of this period has not been specifically studied, and its study and research has a very important scientific, educational, political and educational significance.

First of all, the literature of this period is extremely important in that it constituted an important stage in our literature, which has undergone centuries of evolution. "Important features of the literature of socialist realism, such as revolutionary romance, expression of advanced socialist ideas, realistic depiction of life, are characteristic features of revolutionary poetry. Indeed, as the scholar rightly points out, each of us must understand that the consistent study of literary sources, the transmission of accurate information to the next generation, as well as the literature of this period, which is an important source of independence of the Uzbek people.

There is a folk pain in a play, large or small, poetic or prose, created during this period. The main purpose of this study is to study the literature of this period, first of all, to identify the main trends, to study the ideological currents and directions in a methodological way, to objectively assess the work of a number of artists, thus showing the true picture of the literature of 1905-1917. was. One of the central issues of the literature of this period was the 
CURRENT RESEARCH JOURNAL OF PHILOLOGICAL SCIENCES 2(10): 104-

107, October 2021

DOI: https://doi.org/10.37547/philological-crjps-02-10-20

ISSN 2767-3758

(C)2021 Master Journals

Crossref do

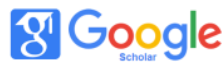

Accepted $26^{\text {th }}$ October, 2021 \& Published $31^{\text {th }}$ October, 2021

reflection of the revolutionary ideas in the country on fiction. The researcher compares it with Russian literature, noting that the literature of this period is extremely complex and full of contradictions. After the defeat of the 1905 revolution, depression and confusion arose in a very large part of the Russian artistic intelligentsia. The creators drew themselves into mysticism and eroticism, avoiding the actual issues of real reality. Various decadent organizations were formed. "... In general, 19071917 deserves to be called the most shameful, the most embarrassing decade in the history of the Russian intelligentsia," said Gorky.

In 1961, the initiatives of scientists of Tashkent State University The existence of such phenomena as mysticism, erotica, bourgeois nationalism in the Uzbek literature of the twentieth century complicates the study of the literature of this period. B. Kasimov notes that the study of Uzbek literature of the early twentieth century in two aspects: literaryhistorical and problem-oriented gives good results. In general, a lot of work has been done to collect and publish the works of a number of representatives of the literature of this period. Fundamental research on the work of Hamza Hakimzoda Niyazi was carried out by Yu.Sultanov and L.Kayumov. Sadriddin Aini's 8 volumes were published in Uzbek and a number of researches were created about him.

In 1951, 1956, 1976 Avaz Otar's and in 1958 Zavkiy's Selected Works were published. Candidate's dissertations on them (H.Razzakov "Life and work of Zavkiy", T., 1953; V.Mirzaev "Avaz Otar oglu. Life and work". T., 1961) were defended, treatises (H.Razzokov, Zavkiy. Uzdavnashr , T., 1955, Yu.Yusupov, Avaz. T., 1954, G.V.Mirzaev. Avaz Otar ogli- enlightener and revolutionary democrat. T., 1961). The 70s further expanded the study of the works of representatives of the literature of this period.
U.Dolimov's "Life and work of the Uzbek poet and enlightener Ibrat", M.Madgaziev's "Rojiy Margilani and his poetic skill", F.Musamuhammedova's "Poor life and work", M.Pirnazarov's "Creative way of Mutrib Khonaharobi" were written dissertations. Similarly, samples of the works of Khislat, Faqiri, Dilshod, Sidiqi-Ajzi, Chokar, Abdulla Avloni were published. These works provide general information about their life and work. Very little of his creative heritage had been studied.

In particular, in the section "The emergence and peculiarities of Uzbek revolutionary poetry" in the pamphlet "Izlay-izlay tapganim" Begali Kasimov quotes a poem by Abdullah Avloni "Family Discussion" written in 1915. And in this poem the pros and cons of science are compared. Let us pay attention to this passage from the ignorant mother tongue in the poem:

Ўкубон ўғлингиз бўлурми имом?

Мулладан қадрлик шу кунда авом!

Ўқуганни бирими Ахмаджон,

Егали уйида топилмас нон.

Мени сўзимни тингланг, эй отаси,

Ўқуғонига эр эмиш пушаймон.

It is clear from the analysis of this poem that man cannot be happy with knowledge alone. Science can be a vehicle for the future, but there is another side to the issue. Abdullah Avloni's 1913 book, "Turkish Gulistan or Morality," had a similar idea: Americans plant one packet of wheat and get twenty packets of wheat. The Europeans will return our five-penny cotton and sell it to us for twenty-five rubles! But we Asians, especially Turkestans, sell buttocks, chew chandir, buy sour cream, eat milk, and bite bread instead of bread! In short, in order to be in line with modern times, it is necessary to have economy, honesty, endless efforts, inexhaustible 
CURRENT RESEARCH JOURNAL OF PHILOLOGICAL SCIENCES 2(10): 104-

107, October 2021

DOI: https://doi.org/10.37547/philological-crjps-02-10-20

ISSN 2767-3758

(C2021 Master Journals

Crossref doi

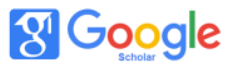

Accepted $26^{\text {th }}$ October, 2021 \& Published $31^{\text {th }}$ October, 2021

zeal along with science and enlightenment ..."

Ёки Анбар Отиннинг:

Маризинг бир тарафдин, бир тарафдин

хорсан, миллат!

Бадандан доимо қон олдурар беморсан, миллат!

Дилшод Барнонинг :

Олма, анору мевалар кони,

Аммо мевага зор боғбони.

Буғдой нонини кўрмас дехқони,

Пахта экади, йиртиқ чопони,

Фарғона замини хусни !

Нодим Намангонийнинг деққонлар хаётидан олинган бир шеърида:

Хўкузлари похол дер, қўшчиси ош ила нон,

Нақдина йўқ қўлида, бисёр дили паришон.

Юз минг хаёл бирла дармонда у харосон,

Онбор пулию,ўлпон бағини айлабон қон...

Абдулла Авлоний:

Камбағални мухтож қилди бир парча нонга,

Катта-катта тўй қилсун деб бойни яратди.

Камбағаллар мошхўрдани явғон ичадир,

Ёғлик палов бой есун деб мойни яратди...

Begali Kasimov analyzes many poems that have acquired a social spirit, such as He notes that the above-mentioned examples of Uzbek poetry have begun to pay more attention to social relations.

In the process of research, the scientist skillfully uses the opportunities of the sociological method. For, "Literary masterpieces are created in a certain cultural and social environment, and while talented people create in a certain historical period, the study of fiction from a sociological point of view, in harmony with other most effective and modern methods, as well as human life, social life It is natural that the research will continue on the basis of the principles of "

\section{REFERENCES}

1. B.Qosimov. (2008). History of Uzbek literature and literary relations. Tashkent: -Science and technology\|. - pp. 104-118 (B.Qosimov. O’zbek adabiyoti va adabiy aloqalari tarixi. - T.:«Fan va texnologiya», 2008, B -104-118).

2. Central Asia in the early twentieth century: the struggle for reform, renewal, development and independence (Jadidism, autonomy, independence). Proceedings of the International Conference. - Tashlent: -Manaviyat||. 2001. - p. 14 (Markaziy Osiyo XX ASR boshida: islohotlar, yangilanish, taraqqiyot va mustaqillik uchun kurash (jadidchilik, muxtoriyatchilik, istiqlolchilik) Xalqaro konferentsiya materiallari, T.: Ma'naviyat, 2001.B-14)

3. Turaeva U. R. (2020) The Scientific Value of Research on Mirmukhsin Fikriy //The American Journal of Social Science and Education Innovations. - Tashkent. 2.- №. 08. - p. 583

4. Turaeva Umriniso Rakhmatovna. Study of Central Asian studies abroad. Republican Multidisciplinary Scientific-Remote Online Conference on the Harmony of Science, Education and Innovation in Renewed Uzbekistan. Part 5. - p. 190

5. Turaeva U. R. (2021) The Tatar press and Turkestan Jadidism In The researches of Begali Kasimov. Asian Journal of Multidimensional Research (AJMR) DOI:10.5958/2278-53.2021.00191.9 